\title{
Clinical risk scores for the prediction of incident atrial fibrillation: a modernized review
}

\author{
ANNA MARIA LOUKA ${ }^{1,2}$, CHRISTOS TSAGKARIS $^{3}$, ALEXANDRA STOICA $^{1}$ \\ ${ }^{1}$ Gr. T. Popa, University of Medicine and Pharmacy, 16 Universității Str., Iași 700115, Romania \\ ${ }^{2}$ University of Thessaly, Faculty of Medicine, Larissa 41334, Greece \\ ${ }^{3}$ University of Crete, Faculty of Medicine, Heraklion,71003, Heraklion, Crete, Greece
}

\begin{abstract}
Atrial fibrillation (AF) is considered the most common sustained arrhythmia. Major cardiovascular risk factors that have been identified to initiate and perpetuate AF include age, sex, arterial hypertension, heart failure, valvular heart disease and diabetes mellitus. In the literature, several studies aimed to formulate easily - applied and accurate risk stratification scores, based on antecedent cardiovascular events, comorbidities and biomarkers for the prediction of new-onset AF. The present narrative review addresses the most universally accepted and efficient clinical scores, with an extended applicability in different populations and ages, particularly scores derived from the Framingham Heart Study, the Atherosclerosis Risk in Communities, the Malmo Diet and Cancer Study, as well as the CHARGE-AF, the CHADS2, $\mathrm{CHA}_{2} \mathrm{DS}_{2}-\mathrm{VASc}, \mathrm{HATCH}$ and CH2EST scores. Identification of incident AF can be challenging, thus dictating for utilization of validated clinical instruments in everyday clinical practice.
\end{abstract}

Key words: atrial fibrillation/diagnosis, cardiac arrhythmias/atrial fibrillation, cardiovascular diseases/epidemiology, ethnic groups, prognosis, risk assessment, risk factors.

What is new? What is important?
The clinical assessment of cardiovascular risk through easily applicable risk scores can accurately predict incident atrial fibrillation.

\section{INTRODUCTION}

Atrial fibrillation (AF) is the most common sustained arrhythmia encountered in clinical practice. Major risk factors include age, gender, arterial hypertension, diabetes mellitus, artery disease, heart failure, pulmonary disease, as well as structural heart disease [1]. Lately, a steady increase in the prevalence [2] and incidence rates of AF has been observed. Although the actual data regarding the overall AF incidence is inconsistent, sustaining significant differences between inpatient and outpatient settings, the largest dynamic range involving the incidence rates over time was documented in individuals aged 85 years or older [3]. $\mathrm{AF}$ is a significant risk factor for serious adverse cardiovascular events, such as myocardial infarction, heart failure [4] and ischemic stroke, with approximately one-third of all strokes globally accredited to AF [5]. In the Framingham Study, the annual risk of stroke attributable to AF was $1.5 \%$ among patients aged 50-59 years and could reach up to $23.5 \%$ in patients over 80 years of age [6]. Arrhythmiccaused strokes are often more severe than nonarrhythmic-related strokes, with the risk of AFrelated stroke mortality increasing from $1.5 \%$ in those aged 50-59 years to $24 \%$ in those aged 80-89 years [6].

Hence, developing risk scores to predict an individual's absolute risk of developing this arrhythmia, with a high clinical applicability and specificity, will substantially aid the diagnosis of atrial fibrillation. Moreover, clinicians will be able to further assess clinical and non-clinical biomarkers and lastly guide them towards a more comprehensive and targeted treatment.

This narrative review summarizes current evidence of using relevant clinical scoring systems for the prediction of new-onset atrial fibrillation. The authors evaluated original investigations published in 
PubMed from 1995 to 2020, using keywords such as clinical scores, scoring systems, prediction and atrial fibrillation. We sought to evaluate the efficacy and accuracy of risk predictive systems in healthy individuals, without previously diagnosed arrhythmias, stroke, catheter ablation or cardiac surgery, of different populations - Asians, Caucasians, African Americans and ages older than 18 years.

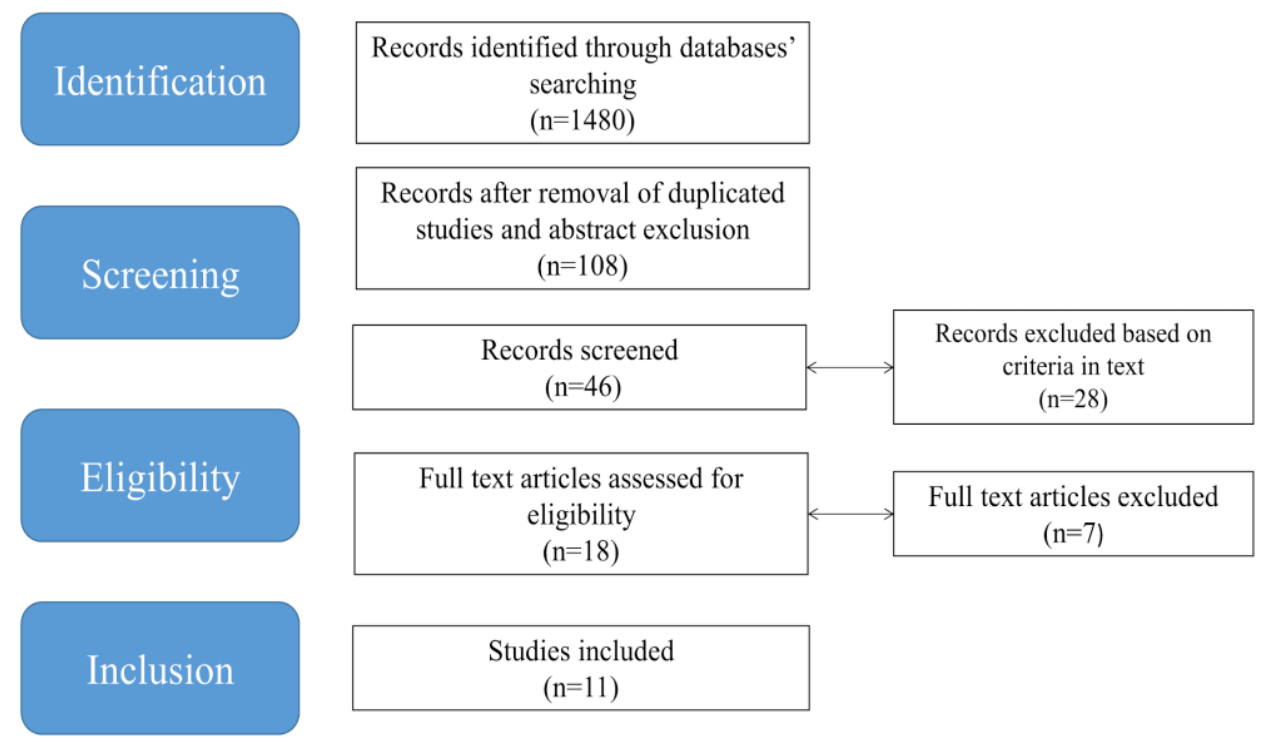

Figure 1. Included studies of the narrative review.

To our knowledge, a standardized integrative instrument of multiple risk factors able to accurately establish an individual's lifetime risk to develop $\mathrm{AF}$ is unavailable. However, recent studies have developed and examined several potential AF risk scores, for everyday use in the clinical practice. Their development originated from community-based studies, in which the primary focus was identification of cardiovascular risk factors. A summarizing table of the clinical scores, their study population characteristics and parameters investigated can be found at the end of the article (Table 1).

\section{Scoring systems stemming from the Framingham Heart Study}

Firstly, the Framingham Heart Study (FHS), which assessed a 10-year risk prediction model with clinical and electrocardiographic parameters, identified a $10 \%$ of study participants with incident atrial fibrillation, after a 10-year follow-up [7]. The incorporation of echocardiographic parameters may improve performance slightly, as observed in secondary analyses. The risk score is reasonably accurate for stratification of individuals into risk categories, with similar accuracy across both sexes, young adults and elderly populations. However, this score was applied in white population, while its utility to predict the 10-year risk of developing $\mathrm{AF}$ in non-whites was uncertain. Luckily, a secondary analysis validating the score in whites and African Americans, concluded that the risk of incident $\mathrm{AF}$ in community, could be assessed reliably [7]. A major limitation of the study was the exemption of thyroid status and physical activity, thus declining risk prediction ability in a subset of patient groups [6,7].

\section{Scoring systems stemming from the Atherosclerosis Risk in Communities Study}

Secondly, the Atherosclerosis Risk in Communities Study (ARIC), in a prospective, biracial (whites and blacks) community-based cohort, developed an additional risk score model, in which commonly identified risk factors, were assimilated to develop a 10-year risk score of new-onset AF, showing a moderately good discrimination under the Cox regression model [8]. Interestingly, the study found the incidence of $\mathrm{AF}$ to be greater in whites than in blacks. Nevertheless, most risk factors predicted AF by race in a similar manner [9], while the Framingham study performed better in predicting $\mathrm{AF}$ in whites, than blacks. Furthermore, an interaction with race and left ventricular hypertrophy (LVH), as well as interactions of diabetes and coronary heart disease (CHD) with age were also found during the study $[8,9]$. 
Table 1

Summary of included clinical scores for the prediction of new-onset atrial fibrillation

\begin{tabular}{|c|c|c|}
\hline CLINICAL SCORE & STUDY POPULATION & VARIABLES \\
\hline FHS & $\begin{array}{ll}\text { - } & 4,764 \text { individuals } \\
\text { - } & \text { Aged } 45-95 \text { years } \\
\text { - } & \text { White race } \\
\text { - } 10 \text { year-risk score } \\
\text { assessment }\end{array}$ & $\begin{array}{ll}- & \text { Age } \\
- & \text { Sex } \\
- & \text { Body mass index } \\
- & \text { Systolic blood pressure } \\
- & \text { Pulse pressure } \\
- & \text { Hypertension medication } \\
- & \text { PR interval duration } \\
- & \text { ECG left ventricular hypertrophy } \\
-\quad \text { Heart failure } \\
\text { - }\end{array}$ \\
\hline ARIC & $\begin{array}{ll}\text { - } & 15,792 \text { individuals } \\
\text { - } & \text { Aged 45-64 years } \\
\text { Biracial study (whites, } \\
\text { blacks) } \\
\text { 10-year risk score } \\
\text { assessment }\end{array}$ & $\begin{array}{ll}\text { - } & \text { Age } \\
- & \text { Race } \\
- & \text { Height } \\
\text { - } & \text { Smoking } \\
\text { - } & \text { Systolic blood pressure } \\
\text { - } & \text { Hypertension treatment } \\
\text { - } & \text { Coronary heart disease } \\
\text { - } & \text { Heart failure } \\
\text { - } & \text { Left atrial enlargement } \\
- & \text { Cardiac murmur } \\
- & \text { PCG left ventricular hypertrophy } \\
- & \text { Prolonged P wave duration }\end{array}$ \\
\hline CHARGE-AF & $\begin{array}{ll}- & 18,556 \text { individuals } \\
- & \text { Aged 46-94 years } \\
- & \text { Biracial (whites, blacks) } \\
\text { - } & \text { 5-year predictive model }\end{array}$ & $\begin{array}{ll}\text { - } & \text { Age } \\
\text { - } & \text { Race } \\
\text { - } & \text { Anthropometric data } \\
\text { - } & \text { Diastolic blood pressure } \\
\text { - } & \text { Smoking status } \\
\text { - } & \text { Hypertension medication } \\
\text { - } & \text { Past history of myocardial infarction } \\
\text { - } & \text { Past history of heart failure } \\
\text { - } & \text { PR interval duration }\end{array}$ \\
\hline MDCS & $\begin{array}{ll}\text { - } & \text { 30,447 individuals } \\
\text { - } & \text { Age } 44-73 \text { years } \\
& \text { White race }\end{array}$ & $\begin{array}{ll}\text { - } & \text { Age } \\
\text { - } & \text { Sex } \\
\text { - } & \text { Diastolic blood pressure blood pressure } \\
\text { - } & \text { Antihypertensive treatment } \\
\text { - } & \text { Body mass index } \\
\text { - } & \text { How-density lipoprotein } \\
\text { - } & \text { Current smoking } \\
\text { - } & \text { History of diabetes mellitus } \\
\text { - } & \text { History of myocardial infarction } \\
\text { History of heart failure }\end{array}$ \\
\hline Suita & $\begin{array}{ll}- & 6,898 \text { individuals } \\
& \text { Aged between } 30-79 \\
& \text { years } \\
\text { - } & \text { Asian race } \\
\text { - } & \text { 10-year risk prediction } \\
& \text { model }\end{array}$ & $\begin{array}{ll}\text { - } & \text { Age } \\
\text { - } & \text { Gender } \\
\text { - } & \text { Systolic hypertension } \\
\text { - } & \text { Weight } \\
\text { - } & \text { Drinking status } \\
\text { - } & \text { Coronary artery disease } \\
\text { Smoking status }\end{array}$ \\
\hline
\end{tabular}




\section{Scoring systems stemming from the CHARGE-AF and other studies}

Moreover, the CHARGE-AF score, was developed from a pooled diverse population from 3 large cohorts in the United States, including the Atherosclerosis Risk in Communities study, the Cardiovascular Health Study, and the Framingham Heart Study, with a 5-year risk prediction [2]. Incorporating parameters were readily available in clinical practice, with statistical analysis exhibiting a good discrimination [10]. The electrocardiographic parameters were found to offer no additional predictive ability, as compared to other variables examined. The study validated the derived models in participants from the Age, Gene and Environment-Reykjavik study and the Rotterdam Study, where it was shown that discrimination was acceptable and calibration adequate [10]. Over 26,000 participants were evaluated, with characteristics of age over 45 years and less than 94 years, as well as African Americans and white populations, thus increasing the generalizability over previously established scores [10].

Important mentioning to the Malmö Diet and Cancer Study (MDCS), a prospective cohort study, with a risk model composition of age, sex, hypertension, history of diabetes mellitus and related cardiovascular disease, as well as laboratory biomarkers and individual habits. The model performed with reasonable accuracy in middle-age individuals without disease. Additional biomarkers did not significantly improve the ability to predict 5-year risk of $\mathrm{AF}$ with the exception of natriuretic peptides [11]. In a related publication from the same registry, heart failure and myocardial infarction were considered the strongest risk factors for the occurrence of atrial fibrillation [12].

A primary score, CHADS $_{2}$ was synthesized to evaluate the risk of thromboembolic risk in patients with established AF. Nowadays, using the more recently developed $\mathbf{C H A}_{2} \mathbf{D S}_{2}$-VASc scoring system, by including additional stroke risk factors (vascular diseases and female gender), was suggested to guide clinicians towards a more 
effective antithrombotic therapy for AF patients. However, recent reports have implied that the aforementioned risk scores also are capable of predicting incident AF, mainly due to the assessment of risk factors shared in atrial fibrillation and stroke [13]

Previous studies have focused on white and black individuals, excluding significant populations such as Asians. For this reason, recent studies sought to determine risk factor models predicting AF in participants from Korea, Taiwan and China $[14,15]$. Starting with the evaluation of the CHADS2 score in 702,502 Chinese individuals in Taiwan, aged more than 18 years, with no prior history of cardiac arrhythmias or rheumatic heart disease, it was found very useful in the prediction of AF, identifying an incidence of 1.5 per 1,000 patients [15]. Later on, the HATCH score was evaluated as a prognostic tool for new-onset $\mathrm{AF}$ in Asian subjects, even though it was developed primarily as a score predicting the permutation of paroxysmal AF to persistent by the Euro Heart Survey [16]. The study had a follow up of 9 years and reported an incidence of $1.4 \%$ of new-onset AF from 670804 patients [17]. Overall, it performed very well in risk estimation and stratification of Asian patients for new-onset $\mathrm{AF}$ and furthermore proved an extended use in estimating the individual risk of incidental $\mathrm{AF}$ for patients with different comorbidities, as opposed to risk models like ARIC and FHS. The Suita study from Japan [17] evaluated 6,898 participants between 30-79 years old, without a previously diagnosed cardiac arrhythmia and after evaluating traditional risk factors, the authors were able to identify patients with a 10 year risk of incident AF. However, the clinical score has a certain degree of complexity, while an external validation study of other Japanese cohorts is necessary to validate Suita's findings. Finally, a study involving 471,446 subjects from the Chinese Yunnan Insurance Database and 451,199 subjects from the Korean National Health Insurance Service, aimed to investigate risk factors for incident $\mathrm{AF}$ in Asian subjects. This study indicated the superiority of the C2HEST score in comparison to CHADS2 and CHA2DS2-VASc in predicting incident $\mathrm{AF}$ among these populations [14]. The C2HEST score was developed as a simple clinical tool, incorporating readily variables used in everyday clinical practice [15]. It was later concluded that the C2HEST score was superior to CHADS2 and CHA2DS2-VASc scores in both cohort studies examined in predicting newonset AF.

\section{Critical assessment, limitations and future research}

This narrative review summarizes the existing scoring systems for the prediction of incident $\mathrm{AF}$, in an effort to sparkle evidencebased dialogue on current medical practice, providing grasps for the future. The efficacy of the existing scoring system seemingly varies among different populations. This variation may depend on racial hereditary traits or behavioral risk factors associated with particular populations residing in the United States, in Northern European countries, in Asia and beyond. Indeed, the Framingham study predictive model appears reliable for white Americans, while the ARIC study has shown similar predictive efficacy in both white and African Americans. At the same time, the C2HEST and HATCH scoring systems appear superior for the prediction of AF in Asian populations. Available evidence suggests that the CHA2DS2-VASc scoring system is not only suitable for optimizing antithrombotic treatment but also capable of predicting incident AF [18]. Certainly, the repeatability of these results in different communities and populations ought to be assessed, once relevant evidence becomes available. Finally, yet importantly, a follow-up systematic review or metanalysis would describe the impact of each scoring system in greater depth.

\section{CONCLUSION}

There are several scoring systems with validated efficacy in predicting new-onset atrial fibrillation in different populations. The most significant parameters taken into consideration are age, sex, arterial hypertension, diabetes mellitus and heart disease. The Framingham study has elucidated the potential benefit from incorporating echocardiographic indices in the existing scoring systems. Despite their differences, all the reviewed studies, including the CHARGE-AF, the Malmo Diet and Cancer Study and 
Atherosclerosis Risk in Communities study yielded the significance of the aforementioned factors, whose modifiable components can be addressed in a preventive and outpatient practice context. Incorporating this evidence in everyday clinical practice can significantly increase the detection of early episodes of the arrhythmia, hence decreasing atrial fibrillation burden, initiating early anticoagulant therapy and preventing adverse thromboembolic events.

Fibrilația atrială (AF) este una dintre cele mai frecvente aritmii. Factorii de risc importanți cunoscuți a fi implicați în inițierea și persistența AF sunt vârsta, genul, hipertensiunea arterială, insuficiența cardiacă, diabetul zaharat și boala valvulară. În literatură sunt descrise mai multe scoruri ce au ca scop stratificarea riscului pentru dezvoltarea AF. Articolul de față prezintă succint cele mai importante scoruri cu aplicabilitate crescută, precum cele din studiul Framingham, CHARGE-AF, CHADS2, CHA ${ }_{2} D S_{2}-V A S c, H A T C H$ și scorul CH2EST. Identificarea AF incidente reprezintă o provocare și sunt astfel necesare instrumente clinice validate în practica curentă.

Correspondence to: Anna Maria Louka, University of Medicine and Pharmacy Gr. T. Popa Iași, 16 Universității Str., Iași 700115, Romania

University of Thessaly, Faculty of Medicine, Larissa 41334, Greece.

Telephone: +306907674686

E-mail: dr.louka.annamaria@gmail.com

Conflicts of interest disclosure: The authors declare that there are no conflicts of interest with regard to this study.

\section{REFERENCES}

1. BENJAMIN A., LEVY D., VAZIRI SM., D’AGOSTINO RB., BELANGER AJ., WOLF P. Independent risk factors for atrial fibrillation in a population based cohort study. JAMA 1994, Vol.271, No.11.

2. GO A.S., HYLEK E.M, PHILLIPS K.A., YUCHIAO C., HENAULT L.E., SELBY J.V., et al. Prevalence of diagnosed atrial fibrillation in adults: national implications for rhythm management and stroke prevention: the AnTicoagulation and Risk Factors in Atrial Fibrillation (ATRIA) Study. JAMA 2001;285:2370-5.

3. WILLIAMS BA, CHAMBERLAIN AM, BLANKENSHIP JC, HYLEK EM, VOYCE S, Trends in atrial fibrillation incidence rates within an integrated health care delivery system, 2006 to 2018. JAMA Netw Open. 2020;3(8):e2014874

4. SOLIMAN E.Z., SAFFORD M.M., MUNTNER P., KHODNEVA Y., FARAH Z. DAWOOD FZ., et al. Atrial fibrillation and the risk of myocardial infarction. JAMA Intern Med 2014;174:107-14.

5. O'NEAL W.T., QURESHI W., ZHANG Z.M. Bidirectional association between atrial fibrillation and congestive heart failure in the elderly. J Cardiovasc Med (Hagerstown) 2016;17:181-6.

6. ALONSO A., ALMUWAQQAT Z., CHAMBERLAIN A. Mortality in atrial fibrillation. Is it changing? [published online ahead of print, 2020 Oct 27]. Trends Cardiovasc Med. 2020;S1050-1738(20)30133-X.

7. SCHNABEL RB, LARSON MG, YAMAMOTO JF, SULLIVAN LM., PENCINA MJ., MEIGS JB., et al. Relations of biomarkers of distinct pathophysiological pathways and atrial fibrillation incidence in the community. Circulation. 2010;121(2):200-207.

8. LIN L, SELVIN E, LUTSEY P, HOOGEVEEN R, O'NEAL W., SOLIMAN E.Z., et al. Association of N-terminal pro B-type natriuretic peptide change with the risk of atrial fibrillation in the ARIC cohort. Am Heart J 2018;204:119-127.

9. CHAMBERLAIN AM, AGARWAL SK, FOLSOM AR, SOLIMAN EZ, CHAMBLESS LE, CROW R. et al. A clinical risk score for atrial fibrillation in a biracial prospective cohort (from the Atherosclerosis Risk in Communities [ARIC] study). Am J Cardiol. 2011; 107(1):85-91.

10. ALONSO A, KRIJTHE BP, ASPELUND T, STEPAS KA, PENCINA MJ, MOSER CB, et al. Simple risk model predicts incidence of atrial fibrillation in a racially and geographically diverse population: the CHARGE-AF consortium. J Am Heart Assoc. 2013; 2(2):e000102.

11. Swedish Cohort Consortium (Cohorts.se) (2011). Malmö Diet Cancer (Identifier AND-ID: EXT 0012). Retrieved from https://snd.gu.se/en/catalogue/study/ext0012 (last accessed: 11/11/2020).

12. SMith JG, PLATONOV PG, HEDBlad B, ENGSTROM G, MELANDER O. Atrial fibrillation in the Malmö Diet and Cancer study: a study of occurrence, risk factors and diagnostic validity. Eur J Epidemiol. 2010 Feb;25(2):95-102.

13. SCHNABEL RB, LARSON MG, YAMAMOTO JF, SULLIVAN LM, PENCINA MJ, MEIGS JB, et al. Relations of biomarkers of distinct pathophysiological pathways and atrial fibrillation incidence in the community. Circulation. 2010;121(2):200-207. 
14. LI YG, PASTORI D., FARCOMENI A, YANG PS, JANG E, JOUNG B., et al. A Simple Clinical Risk Score (C2HEST) for Predicting Incident Atrial Fibrillation in Asian Subjects Derivation in 471,446 Chinese Subjects, With Internal Validation and External Application in 451,199 Korean Subjects. CHEST 2019; 155(3):510-518.

15. CHAO TF, LIU CJ, CHEN SJ, WANG KL, LIN YJ, CHANG SL, et al., CHADS2 score and risk of new-onset atrial fibrillation: A nationwide cohort study in Taiwan. International Journal of Cardiology 168 (2013) 1360-1363.

16. SUENARI K., CHAO TF., LIU CJ. KIHARA Y., CHEN TJ., CHEN SA. Usefulness of HATCH score in the prediction of new-onset atrial fibrillation for Asians. Medicine (2017) 96:1(e5597).

17. KOKUBO Y., WATANABE E., HIGASHIYAMA A., NAKAO YM., KUSANO K., MIYAMOTO Y. Development of a Basic Risk Score for Incident Atrial Fibrillation in a Japanese General Population - The Suita Study - Circ J 2017; 81: 1580-1588.

18. SMITH JG., NEWTON-CHEH C., ALMGREN P, STRUCK J., MORGENTHALER NG., BERGMANN A., et al. Assessment of conventional cardiovascular risk factors and multiple biomarkers for the prediction of incident heart failure and atrial fibrillation. J Am Coll Cardiol. 2010;56(21):1712-1719.

Received $13^{\text {th }}$ November 2020 